\title{
The Protective Role of Resveratrol against Arsenic Trioxide-Induced Cardiotoxicity
}

\author{
Weiqian Zhang, ${ }^{1}$ Changming Guo, ${ }^{2}$ Ruifeng Gao, ${ }^{2}$ Ming Ge, \\ Yanzhu Zhu, ${ }^{3}$ and Zhigang Zhang ${ }^{1}$ \\ ${ }^{1}$ College of Veterinary Medicine, Northeast Agricultural University, Harbin 150030, China \\ ${ }^{2}$ College of Animal Science and Veterinary, Medicine, Jilin University, Changchun 130062, China \\ ${ }^{3}$ Institute of Special Economic Animal and Plant Science, Chinese Academy of Agricultural Sciences, Jilin 132109, China \\ Correspondence should be addressed to Zhigang Zhang; zzgneau@yahoo.com.cn
}

Received 2 February 2013; Revised 30 August 2013; Accepted 17 September 2013

Academic Editor: Ka Kit Hui

Copyright (C) 2013 Weiqian Zhang et al. This is an open access article distributed under the Creative Commons Attribution License, which permits unrestricted use, distribution, and reproduction in any medium, provided the original work is properly cited.

\begin{abstract}
Arsenic trioxide $\left(\mathrm{As}_{2} \mathrm{O}_{3}\right)$ shows substantial anticancer activity in patients with acute promyelocytic leukemia (APL). Unfortunately, limiting the application of this effective agent to APL patients is severe cardiotoxicity. Resveratrol, the natural food-derived polyphenolic compound, is well known for its antioxidant properties and protects the cardiovascular system. But the potential role of resveratrol against $\mathrm{As}_{2} \mathrm{O}_{3}$ in heart via nuclear factor erythroid 2-related factor 2 (Nrf2) and heme oxygenase-1 (HO-1) is unclear. The present study evaluated the effects of pretreatment with resveratrol and $\mathrm{As}_{2} \mathrm{O}_{3}$ on oxidative stress and cardiac dysfunction in rat. In the present study, resveratrol decreased $\mathrm{As}_{2} \mathrm{O}_{3}$-induced reactive oxygen species generation, oxidative DNA damage, and pathological alterations. In addition, cardiac dysfunction parameters, intracellular calcium and arsenic accumulation, glutathione redox ratio, and cAMP deficiency levels were observed in $\mathrm{As}_{2} \mathrm{O}_{3}$-treated rats; these changes were attenuated by resveratrol. Furthermore, resveratrol significantly prohibited the downregulation of both Nrf2 and HO-1 gene expressions that were downregulated by $\mathrm{As}_{2} \mathrm{O}_{3}$, whereas resveratrol did not alter $\mathrm{As}_{2} \mathrm{O}_{3}$-induced nitric oxide formation. Thus, the protective role of resveratrol against $\mathrm{As}_{2} \mathrm{O}_{3}$-induced cardiotoxicity is implemented by the maintenance of redox homeostasis (Nrf2-HO-1 pathway) and facilitating arsenic efflux. Our findings suggest coadministration with resveratrol, and $\mathrm{As}_{2} \mathrm{O}_{3}$ might provide a novel therapeutic strategy for APL.
\end{abstract}

\section{Introduction}

High concentration of dietary exposure to arsenic and arsenic compounds is considered to increase the risk of human carcinogenesis [1]. However, arsenic has attracted worldwide interest because it shows substantial anticancer activity in individuals with acute promyelocytic leukemia (APL). Unfortunately, the use of these drugs is associated with cardiotoxicity (including a prolonged QT interval and prolonged action potential), torsades de pointes, and sudden cardiac death [2-5]. This may involve multiple mechanisms, including the generation of reactive oxygen species (ROS) in cardiomyocytes, oxidative DNA damage, and arsenic accumulation, [6-8]. However, proper drug that has the protective ability of the heart to protect against arsenic toxicity in the clinical practice is insufficient.
Resveratrol $\left(3,5,4^{\prime}\right.$-trihydroxy-trans-stilbene) is a plantderived polyphenolic compound belonging to a class of stilbenes, found abundantly in certain grapes, roots, berries, and peanuts. Resveratrol has been shown to exert various cardiovascular protective effects in myocardial ischemicreperfusion injury and atherosclerosis $[9,10]$, metabolic diseases [11], and in aged mice [12-14]. It was also reported that resveratrol could protect against cardiotoxicity in $\mathrm{As}_{2} \mathrm{O}_{3}$ exposed mouse by the increase in the activities of antioxidant enzymes in the heart and antiapoptotic activity in $\mathrm{H} 9 \mathrm{c} 2$ cardiomyocytes [15]. However, whether resveratrol can attenuate the $\mathrm{As}_{2} \mathrm{O}_{3}$-induced cardiotoxicity mediated by improving cardiac function through redox signaling mechanisms and the decrease in arsenic accumulation is yet to be determined. The present study was undertaken to explore this problem. 


\section{Materials and Methods}

2.1. Animals and Chemicals. All procedures used in this study were approved by the Institutional Animal Care and Use Committee of Northeast Agricultural University. Six-weekold male Wistar rats from the Experimental Animal Centre of Harbin Medical University (Harbin, China) were housed in the Animal Quarters of the Northeast Agricultural University at $22^{\circ} \mathrm{C}$ on a 12 -hour light-dark cycle. They were allowed free access to standard rodent chow and tap water. Thirtytwo rats were randomly assigned to four groups: control, $\mathrm{As}_{2} \mathrm{O}_{3}$-treated, $\mathrm{As}_{2} \mathrm{O}_{3}+$ resveratrol, and resveratrol-treated. All treatments were given via the caudal vein on alternate days for 4 days (i.e., days: 1, 3, 5, and 7) with measurements being made on the 8th day. $\mathrm{As}_{2} \mathrm{O}_{3}$ (Harbin Yida Pharmaceutical Co. Ltd., Harbin, China) was administered $3 \mathrm{mg} / \mathrm{kg}$; resveratrol (Sigma-Aldrich, St. Louis, MO, USA) was administered $8 \mathrm{mg} / \mathrm{kg}$; in the $\mathrm{As}_{2} \mathrm{O}_{3}+$ resveratrol group, rats were given resveratrol $1 \mathrm{~h}$ prior to $\mathrm{As}_{2} \mathrm{O}_{3}$ administration. Dose selection is based on the literature [14]. An equal amount of $0.9 \%$ normal saline was administered as vehicles to control rats. On the 8th day, rats were given ether anesthesia and sacrificed.

2.2. Biochemical Analysis. Blood was collected from puncturing the retro-orbital venous sinus and immediately centrifuged at $8,000 \times \mathrm{g}$ for $10 \mathrm{~min}$ at $4^{\circ} \mathrm{C}$ to separate serum. Serum lactate dehydrogenase (LDH), creatine kinase (CK), creatine kinase $\mathrm{MB}$ (CK-MB), and aspartate aminotransferase (AST) were measured using a commercial kit from Jiancheng Bio-engineering Institute (Nanjing, China), following the manufacturer's instructions.

2.3. Measurement of ROS, 8-Hydroxy-2-deoxyguanosine (8$\mathrm{OHdG}$ ) and the Ratio Reduced Glutathione (GSH) to Oxidized Glutathione (GSSG). Cardiac tissues were homogenized in phosphate-buffered saline ( $\mathrm{pH}$ 7.4) using an Ultrathurax T25 Homogenisator and centrifuged at $10,000 \times \mathrm{g}$ for $10 \mathrm{~min}$ at $4^{\circ} \mathrm{C}$. ROS production of cardiac tissue was determined by $2^{\prime}$, $7^{\prime}$-dichlorofluorescein diacetate (DCF-DA, Invitrogen) assay, in which highly fluorescent DCF can be converted by cellular peroxides, as previously reported by Maxwell et al. [16]. The DNA of each sample was extracted using a DNeasy tissue kit (QIAGEN, Valencia, CA, USA), and 8-OHdG was measured using an oxidative DNA damage enzyme-linked immunosorbent assay (ELISA) kit (Cell Biolaboratories, San Diego, CA, USA), following the manufacturer's instructions. Supernatant glutathione was determined by the method as described in [17], and the ratio of GSH to GSSG was calculated.

2.4. Histological Analysis. Cardiac tissues were quickly removed. For light microscopic (BX-FM; Olympus, Tokyo, Japan) observation, cardiac tissues were fixed by immersion in $10 \%$ formaldehyde solution for $24 \mathrm{~h}$ at $37^{\circ} \mathrm{C}$; then paraffin sections $(4 \mu \mathrm{m})$ were cut and stained with hematoxylin and eosin.

2.5. Determination of Arsenic Accumulation in the Heart. The arsenic contents in cardiac tissues of all rats were analyzed following the method in the literature [18] with an atomic fluorescence spectrometry system (AFS930; Beijing Jitian Instrument Co. Ltd., Beijing, China).

2.6. Measurements of Cytosolic Free Calcium Ion $\mathrm{Ca}^{2+}$ Level. Cardiac cells were digested with $0.25 \%$ trypsinase. The cell suspension was washed twice with Tyrode's Solution (in $\mathrm{mM}: \mathrm{NaCl}, 137 ; \mathrm{KCl}, 5.4 ; \mathrm{MgCl}_{2}$, 1; glucose, 10; HEPES, 10; $\mathrm{CaCl}_{2}, 2 ; \mathrm{pH} 7.4$ ) and loaded with $2 \mu \mathrm{M}$ Fura-2/AM for $30 \mathrm{~min}$ at $37^{\circ} \mathrm{C}$ in culture medium. The cells were washed three times then incubated for an additional $30 \mathrm{~min}$ at $37^{\circ} \mathrm{C}$ to complete probe de-esterification and resuspended in loading buffer at a density of $10^{6}$ cells $/ \mathrm{mL}$. Fluorescence was monitored with a 970 CRT spectrofluorophotometer at $488 \mathrm{~nm}$ for excitation and $530 \mathrm{~nm}$ for emission. Maximum and minimum fluorescence values were obtained by adding $0.1 \%$ Triton X-100 (plus $5 \mathrm{mM} \mathrm{CaCl} 2$ ) and $10 \mathrm{mM}$ EGTA sequentially. $\mathrm{Ca}^{2+}$ levels were calculated as previously described [19].

2.7. cAMP and Nitric Oxide (NO) Concentration Assay. The supernatant of homogenized cardiac tissue was assayed for cAMP and NO concentration using the enzyme immunoassay kit and the method of chemical colorimetry, respectively, following the manufacturer's instructions (Jiancheng Bioengineering Institute (Nanjing, China)).

2.8. Determination of Nuclear Factor Erythroid 2-Related Factor 2 (Nrf2) and Heme Oxygenase-1 (HO-1) mRNA Level by Quantitative Real-Time PCR Assay. Total RNA was extracted from the cardiac tissue samples using the RNAfast $200 \mathrm{Kit}$ (Fastagen, China). The concentration of total RNA in the extract was quantified spectrophotometrically. RNA integrity was evaluated by the proportion of the ribosomal bands (28S:18S) after electrophoresis on $1 \%$ agarose gel in the presence of ethidium bromide. cDNA was synthesized using $5 \mu \mathrm{L}$ of total RNA using the reverse transcriptase M-M LV (Promega), as described by the manufacturer's system [20]. Quantitative real-time PCR was carried out using a SYBR Green PCR kit (Bioteke, Peking, China), and PCR amplification was conducted on an ABI PRISM 7500 Sequence Detector System (Perkin-Elmer Applied Biosystems, Foster City, CA, USA). The primer sequences for the genes are as follows: Nrf-2 Forward: $5^{\prime}$-ACT CAT CGA TCC CCT CAC TG-3', Reverse: $5^{\prime}$-CTA ATG GCA GCA GAG GAA GG-3'; HO-1 Forward: $5^{\prime}$-AAG AGG CTA AGA CCG CCT TC- $3^{\prime}$, Reverse: $5^{\prime}$-GCA TAA ATT CCC ACT GCC AC- $3^{\prime}$; GAPDH Forward: $5^{\prime}$-GCA TGG CCT TCC GTG TTC C$3^{\prime}$, Reverse: $5^{\prime}$-CTC ATT CTT TGG GAC GTG GTG GG-3'. The expression of mRNA level in each sample was normalized against its GAPDH mRNA level.

2.9. Statistical Analysis. Statistical analysis was performed using SPSS ver19.0 (SPSS, Chicago, IL, USA). One-way analysis of variance (Duncan's multiple comparison) was used for the determination of differences in measurements between groups. $P<0.05$ was considered significant. 
TABLE 1: The effect of resveratrol on $\mathrm{As}_{2} \mathrm{O}_{3}$-induced biochemical makers.

\begin{tabular}{lcccc}
\hline & Control & $\mathrm{As}_{2} \mathrm{O}_{3}$ & $\mathrm{As}_{2} \mathrm{O}_{3}+$ resveratrol & Resveratrol \\
\hline AST (U/L) & $156.23 \pm 56.78$ & $282.69 \pm 60.43^{\mathrm{a} * *}$ & $225.78 \pm 58.36^{\mathrm{b} *}$ & $155.34 \pm 53.41$ \\
$\mathrm{LDH}(\mathrm{U} / \mathrm{L})$ & $1050.25 \pm 370.36$ & $2700.45 \pm 380.13^{\mathrm{a} * *}$ & $1680.34 \pm 470.68^{\mathrm{b} *}$ & $1051.37 \pm 360.42$ \\
$\mathrm{CK}(\mathrm{U} / \mathrm{L})$ & $336.98 \pm 48.04$ & $1463.31 \pm 452.16^{\mathrm{a} * *}$ & $597.28 \pm 90.54^{\mathrm{b} * *}$ & $335.62 \pm 50.26$ \\
$\mathrm{CK}-\mathrm{MB}(\mathrm{U} / \mathrm{L})$ & $205.83 \pm 32.32$ & $812.94 \pm 129.85^{\mathrm{a} * *}$ & $407.59 \pm 67.40^{\mathrm{b} * *}$ & $204.30 \pm 30.02$ \\
\hline
\end{tabular}

Values are expressed as mean \pm S.E. for eight rats in each group.

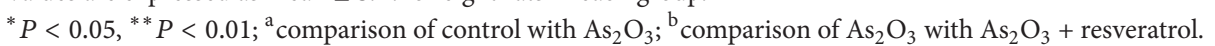

\section{Results}

3.1. The Contents of LDH, AST, CK, and CK-MB in Serum. As shown in Table 1, LDH, AST, CK, and CK-MB release from cardiac cells, in the rat treated with $\mathrm{As}_{2} \mathrm{O}_{3}$, were markedly increased compared with those in the control group $(P<$ $0.05)$. Pretreatment of resveratrol resulted in a significant decrease in plasma LDH, AST, CK, and CK-MB release, $20.21 \%, 37.78 \%, 59.19 \%$, and $49.88 \%$, respectively, compared with that in the $\mathrm{As}_{2} \mathrm{O}_{3}$-treated group, whereas resveratrol alone did not show significant effect on $\mathrm{LDH}, \mathrm{AST}, \mathrm{CK}$, and CK-MB activity.

3.2. Effects of Resveratrol on $\mathrm{As}_{2} \mathrm{O}_{3}$-Induced $\mathrm{ROS}, 8-\mathrm{OHd}$, and GSH/GSSG. After exposure to arsenic for 4 days, the remarkable increase in ROS and 8 -OHdG generation was observed in rats' hearts, compared with that in the control group (Figures 1(a) and 1(b)). However, pretreatment with resveratrol partly abolished these changes. In addition, treatment with resveratrol exposure significantly reversed the decrease in $\mathrm{As}_{2} \mathrm{O}_{3}$-induced the ration GSH/GSSG $(P<0.01)$ (Figure 1(c)).

3.3. Effect of Resveratrol on $\mathrm{As}_{2} \mathrm{O}_{3}$-Induced Cardiomyopathy. Histopathological assessments of different cardiac tissues of rats are shown in Figure 2. Compared with those in the control group, myofibrillar loss and cardiomyocyte necrosis were observed in the hearts of the $\mathrm{As}_{2} \mathrm{O}_{3}$-treated rats (Figure 2(b)). Structural abnormalities in the hearts of $\mathrm{As}_{2} \mathrm{O}_{3}$-treated rats were partly prevented by pretreatment with resveratrol and showed slight myocardial hemorrhage. Resveratrol-treated rats had normal myocardiac morphology (data not shown).

3.4. The Contents of Total Arsenic in the Heart. Figure 3 has shown the contents of total arsenic in the heart. Our results showed that total arsenic content in the heart appeared to be obviously increased compared with $\mathrm{As}_{2} \mathrm{O}_{3}$-treated rats. Pretreatment with resveratrol significantly attenuated arsenic accumulation in the heart compared with that seen in the $\mathrm{As}_{2} \mathrm{O}_{3}$-treated group $(P<0.05)$ (Figure 3 ).

3.5. Effect of Resveratrol on $\mathrm{As}_{2} \mathrm{O}_{3}$-Induced Intracellular Calcium Accumulation. The effects of resveratrol on $\mathrm{As}_{2} \mathrm{O}_{3}$ induced intracellular calcium accumulation in the heart are shown in Figure 4(b). Our data indicated $\mathrm{Ca}^{2+}$ content was markedly greater in $\mathrm{As}_{2} \mathrm{O}_{3}$-treated group than that in the control group $(P<0.01)$, and resveratrol significantly

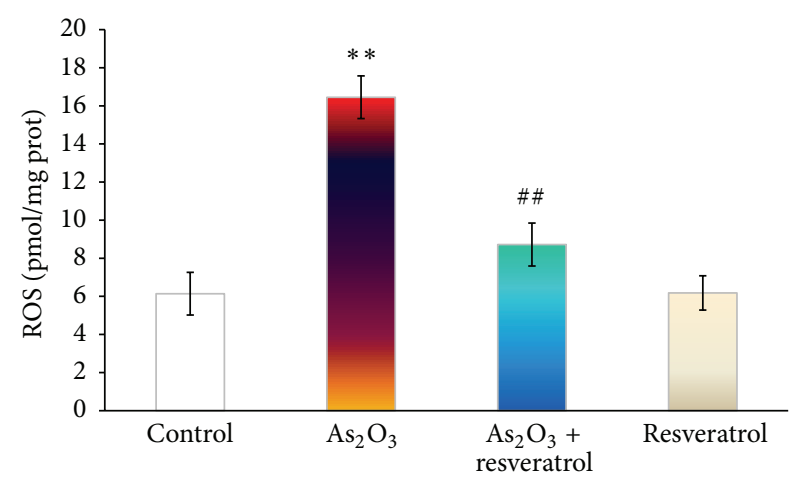

(a)

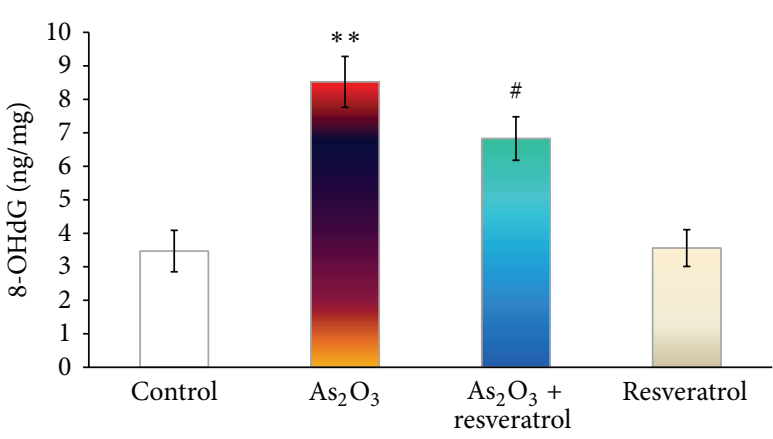

(b)

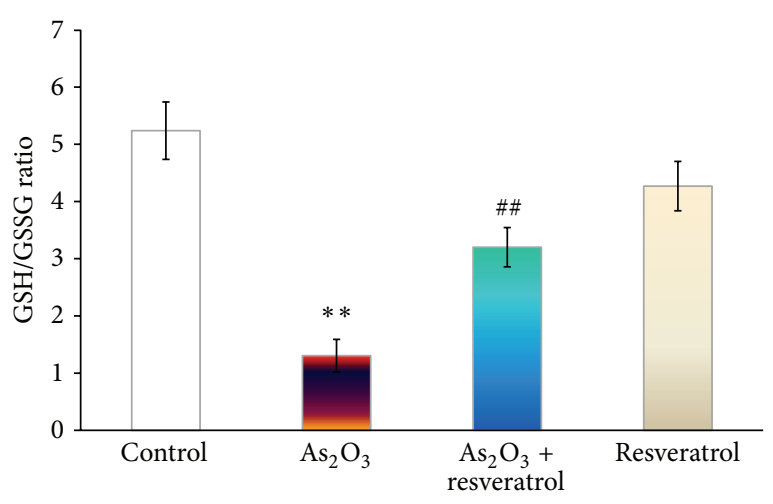

(c)

FIGURE 1: The effect of resveratrol and $\mathrm{As}_{2} \mathrm{O}_{3}$ on ROS (a), 8-OHdG (b), and GSH/GSSG (c) ratio in the heart tissue from control, $\mathrm{As}_{2} \mathrm{O}_{3}$ treated, resveratrol $+\mathrm{As}_{2} \mathrm{O}_{3}$, and resveratrol-treated groups. Values are mean \pm S.E. mean; $n=8 .{ }^{*} P<0.05$ or ${ }^{* *} P<0.01$ versus control group, ${ }^{\#} P<0.05$ or ${ }^{\# \#} P<0.01$ versus $\mathrm{As}_{2} \mathrm{O}_{3}$-treated group. 


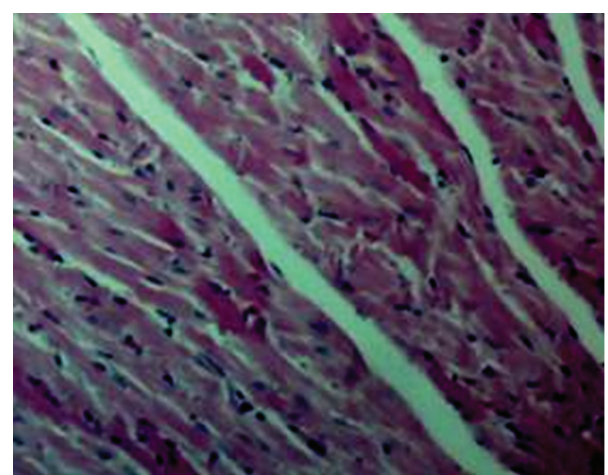

(a)

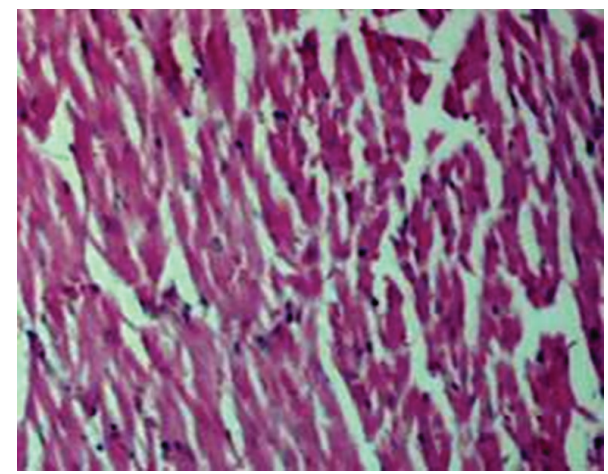

(b)

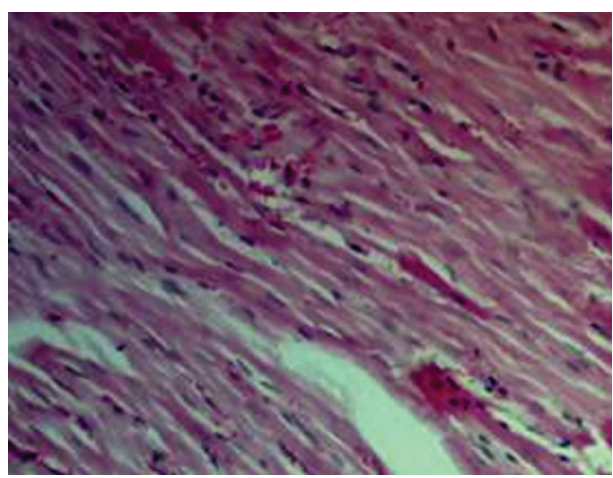

(c)

FIgURE 2: The effect of resveratrol and $\mathrm{As}_{2} \mathrm{O}_{3}$ on cardiac histology. Paraffin sections of heart tissues from control (a), $\mathrm{As}_{2} \mathrm{O}_{3}$-treated (b), and resveratrol $+\mathrm{As}_{2} \mathrm{O}_{3}$ (c) were stained with hematoxylin and eosin ( $\times 100$ magnification).

inhibited this $\mathrm{As}_{2} \mathrm{O}_{3}$-induced that $\mathrm{Ca}^{2+}$ accumulation $(P<$ $0.05)$.

3.6. Effects of Resveratrol on $\mathrm{As}_{2} \mathrm{O}_{3}$-Induced cAMP and $\mathrm{NO}$ in the Heart. To determine the effect of resveratrol on $\mathrm{As}_{2} \mathrm{O}_{3}$ induced cAMP, concentrations in rats treated with $\mathrm{As}_{2} \mathrm{O}_{3}$ and pretreatment with resveratrol were measured. As expected, treatment of rats with $\mathrm{As}_{2} \mathrm{O}_{3}(3 \mathrm{mg} / \mathrm{kg}$ i.v. $)$ significantly decreased cAMP concentrations in the heart compared with saline-treated control group, and pretreatment of resveratrol could partly abolish this decrease in cAMP concentration (Figure 4(a)). In contrast, NO concentration in the heart has

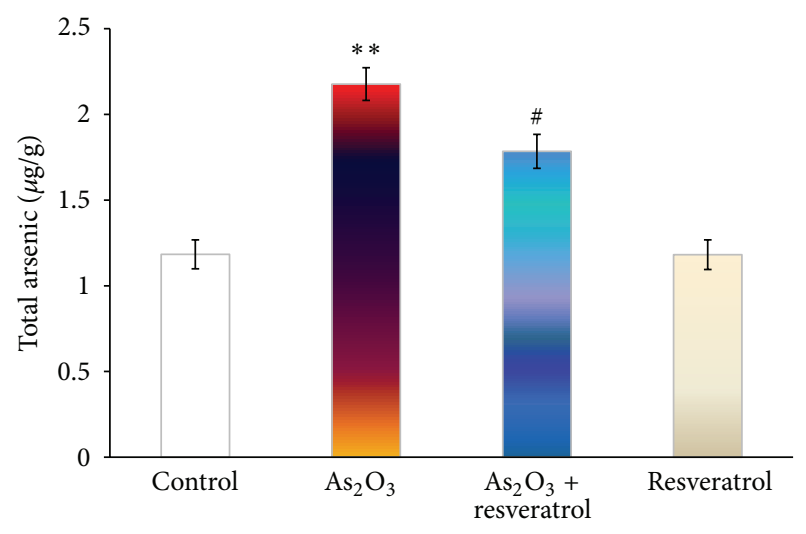

FIgURE 3: The effect of resveratrol and $\mathrm{As}_{2} \mathrm{O}_{3}$ on total arsenic in the heart. The total arsenic of heart tissues from control, $\mathrm{As}_{2} \mathrm{O}_{3}$-treated, resveratrol $+\mathrm{As}_{2} \mathrm{O}_{3}$, and resveratrol-treated groups was quantified by high-performance liquid chromatography-hydride generationatomic fluorescence spectrometry. Values are mean \pm S.E. mean; $n=8 .{ }^{*} P<0.05$ or ${ }^{* *} P<0.01$ versus control group, ${ }^{\#} P<0.05$ or ${ }^{\# \#} \mathrm{P}<0.01$ versus $\mathrm{As}_{2} \mathrm{O}_{3}$-treated group.

no statistical change during exposure to $\mathrm{As}_{2} \mathrm{O}_{3}$ and with or without the administration of resveratrol (Figure 4(b)).

3.7. Effects of Resveratrol on the mRNA Level of HO-1 and Nrf2. To further explore the possible mechanism of $\mathrm{As}_{2} \mathrm{O}_{3}$-induced cardiotoxicity, HO-1 and Nrf2 mRNA with antioxidant and protective properties were selected to determine the effect of resveratrol on cytotoxicity in $\mathrm{As}_{2} \mathrm{O}_{3}$-treated rats. After exposure to $\mathrm{As}_{2} \mathrm{O}_{3}$ on alternate 4 days, both $\mathrm{Nrf} 2$ and $\mathrm{HO}$ 1 gene expressions in the heart were significantly downregulated, compared with the control group (Figure 5). Treatment with resveratrol significantly prohibited the downregulated Nrf2 and HO-1 gene expressions that were downregulated by $\mathrm{As}_{2} \mathrm{O}_{3}$, compared with $\mathrm{As}_{2} \mathrm{O}_{3}$-treated rats $(P<0.01)$.

\section{Discussion}

In this study, we investigated cardiac function associated with Nrf2-HO-1 pathway and arsenic accumulation for the protection of resveratrol against $\mathrm{As}_{2} \mathrm{O}_{3}$-induced cardiac injury in Wistar rats in vivo.

Aposhian and Aposhian [21] described that exposure to inorganic arsenic induces cellular oxidative stress through ROS generation. Several studies have indicated that cardiovascular diseases, such as endothelial dysfunction, ischaemia-reperfusion injury, and atherosclerosis, are linked to the release of intracellular $\operatorname{ROS}[7,22]$. In our studies, $\mathrm{LDH}, \mathrm{AST}, \mathrm{CK}$, and CK-MB release, which are the most important makers of myocardial injury, disorder and necrosis in response to $\mathrm{As}_{2} \mathrm{O}_{3}$ treatment, were increased, especially $\mathrm{CK}-\mathrm{MB}$, which is a more sensitive marker of myocardial injury than total CK activity. In addition, there were various oxidative damages in Wistar rat's heart indicated with the increase of ROS, 8-OHdG formation, and percentage of GSSG/GSH, which resulted in the severe histological alterations, including myofibrillar loss, cardiomyocyte necrosis, 


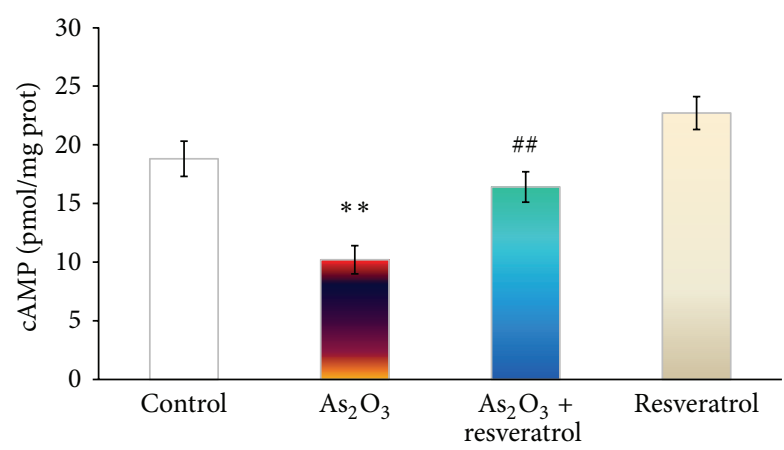

(a)

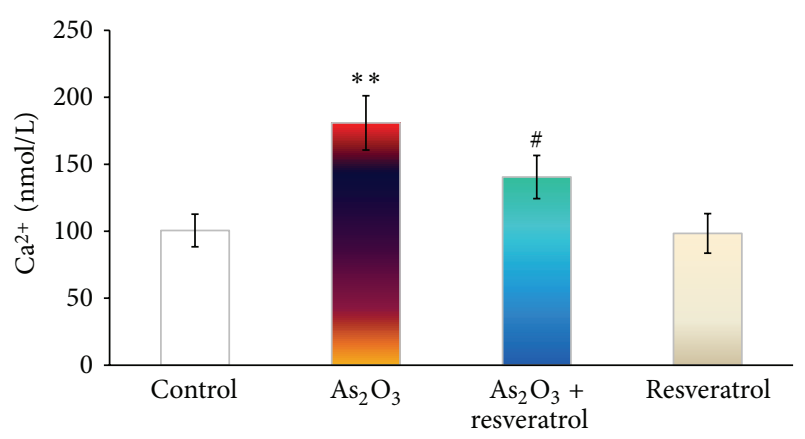

(b)

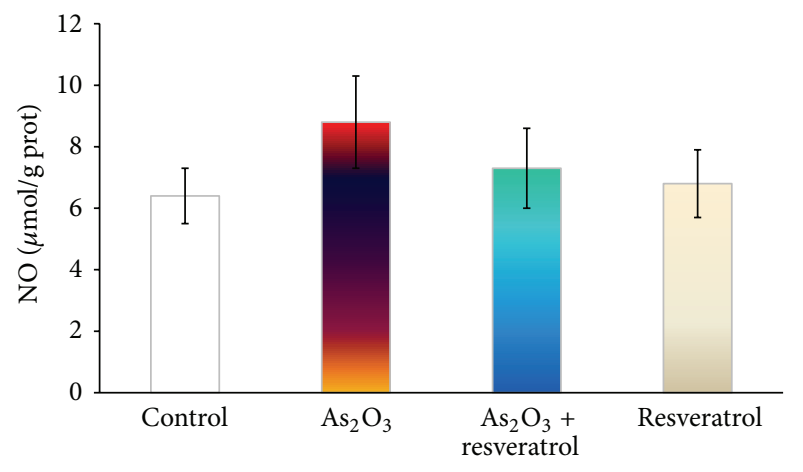

(c)

Figure 4: The effect of resveratrol on $\mathrm{As}_{2} \mathrm{O}_{3}$-induced cAMP (a), $\mathrm{Ca}^{2+}$ (b), and $\mathrm{NO}$ (c) in the heart from control, $\mathrm{As}_{2} \mathrm{O}_{3}$-treated, resveratrol $+\mathrm{As}_{2} \mathrm{O}_{3}$, and resveratrol-treated groups. Values are mean \pm S.E. mean; $n=8 .{ }^{*} P<0.05$ or ${ }^{* *} P<0.01$ versus control group, ${ }^{\#} P<0.05$ or ${ }^{\# \#} P<0.01$ versus $\mathrm{As}_{2} \mathrm{O}_{3}$-treated group.

and myocardial hemorrhage. Consistent with Ermak and Davies's research on ROS-induced $\mathrm{Ca}^{2+}$ dyshomeostasis in the heart [23], our data showed that intracellular calcium accumulation after exposure to $\mathrm{As}_{2} \mathrm{O}_{3}$ is at least partially due to ROS formation induced by $\mathrm{As}_{2} \mathrm{O}_{3}$.

Under normal circumstances, cells can defend against ROS damage by means of endogenous oxidants, such as glutathione, vitamin $\mathrm{C}$, and vitamin $\mathrm{E}$, as well as with the involvement of various peroxidases in the cellular antioxidant systems. Glutathione redox state correlates with the biological status of the cell [24]. On the other hand, Nrf2 has been demonstrated to be a critical transcription factor that binds

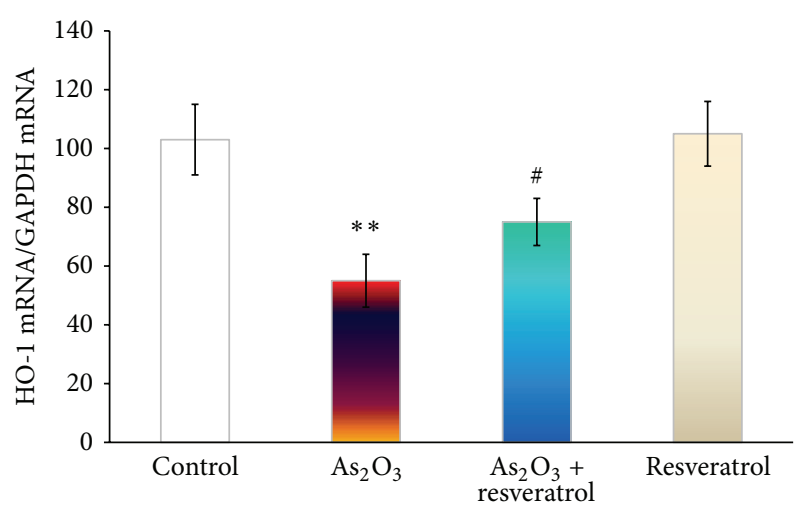

(a)

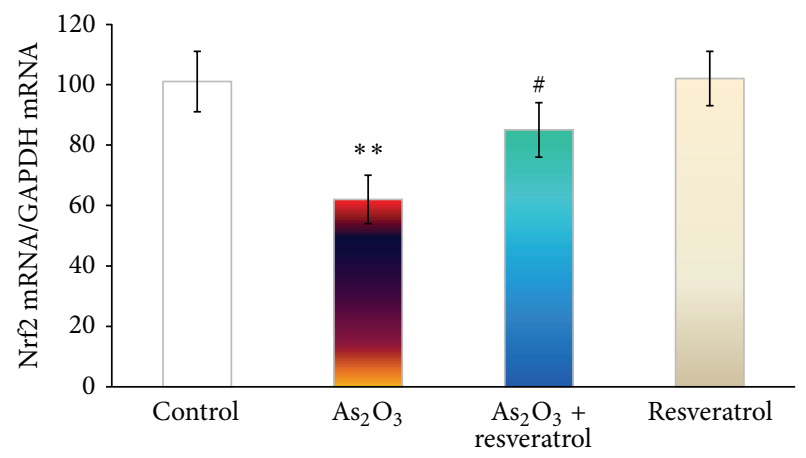

(b)

Figure 5: The effect of resveratrol on $\mathrm{As}_{2} \mathrm{O}_{3}$-inducedHO-1 and $\mathrm{Nrf} 2$ on the mRNA level in the heart from the control, $\mathrm{As}_{2} \mathrm{O}_{3}$-treated, resveratrol $+\mathrm{As}_{2} \mathrm{O}_{3}$, and resveratrol-treated groups. (a) Real-time quantitative PCR analyses of gene expression levels of HO-1 in cardiac myocytes. (b) Real-time quantitative PCR analyses of gene expression levels of Nrf2 in cardiac myocytes. Values are mean \pm S.E. mean; $n=8 .{ }^{*} P<0.05$ or ${ }^{* *} P<0.01$ versus control group, ${ }^{\#} P<0.05$ or ${ }^{\# \#} P<0.01$ versus $\mathrm{As}_{2} \mathrm{O}_{3}$-treated group.

to the antioxidant response element in the promoter region of a number of genes, encoding for phase I and phase II antioxidative enzymes and cytoprotective proteins, such as $\mathrm{NAD}(\mathrm{P}) \mathrm{H}$ :quinone acceptor oxidoreductase 1 , glutathione Stransferases, the glutamyl cysteine ligase catalytic subunit, and multidrug resistance-associated protein [25]. Hence, Nrf2 pathway is presumably the most important pathway in cells to deal with oxidative stress generated from exposure to exogenous and endogenous chemicals [20]. HO-1 is an enzyme with antioxidant and protective properties during cellular stress [20]. After exposure to $\mathrm{As}_{2} \mathrm{O}_{3}(3 \mathrm{mg} / \mathrm{kg}$ every alternative day for 4 days), the antioxidant defense system in rats cannot maintain the depletion. Consequently, we observed significantly a decrease in GSH/GSSG ratio and mRNA expression of $\mathrm{Nrf} 2$ and $\mathrm{HO}-1$ downregulation (Figure 1).

There is a considerable interest in the role of constituent in dietary supplement in the prevention and treatment of cardiovascular disease [23]. Furthermore, natural compounds also modulate ROS accounting for the reduction of cell injury in pathological conditions in heart diseases [26]. 


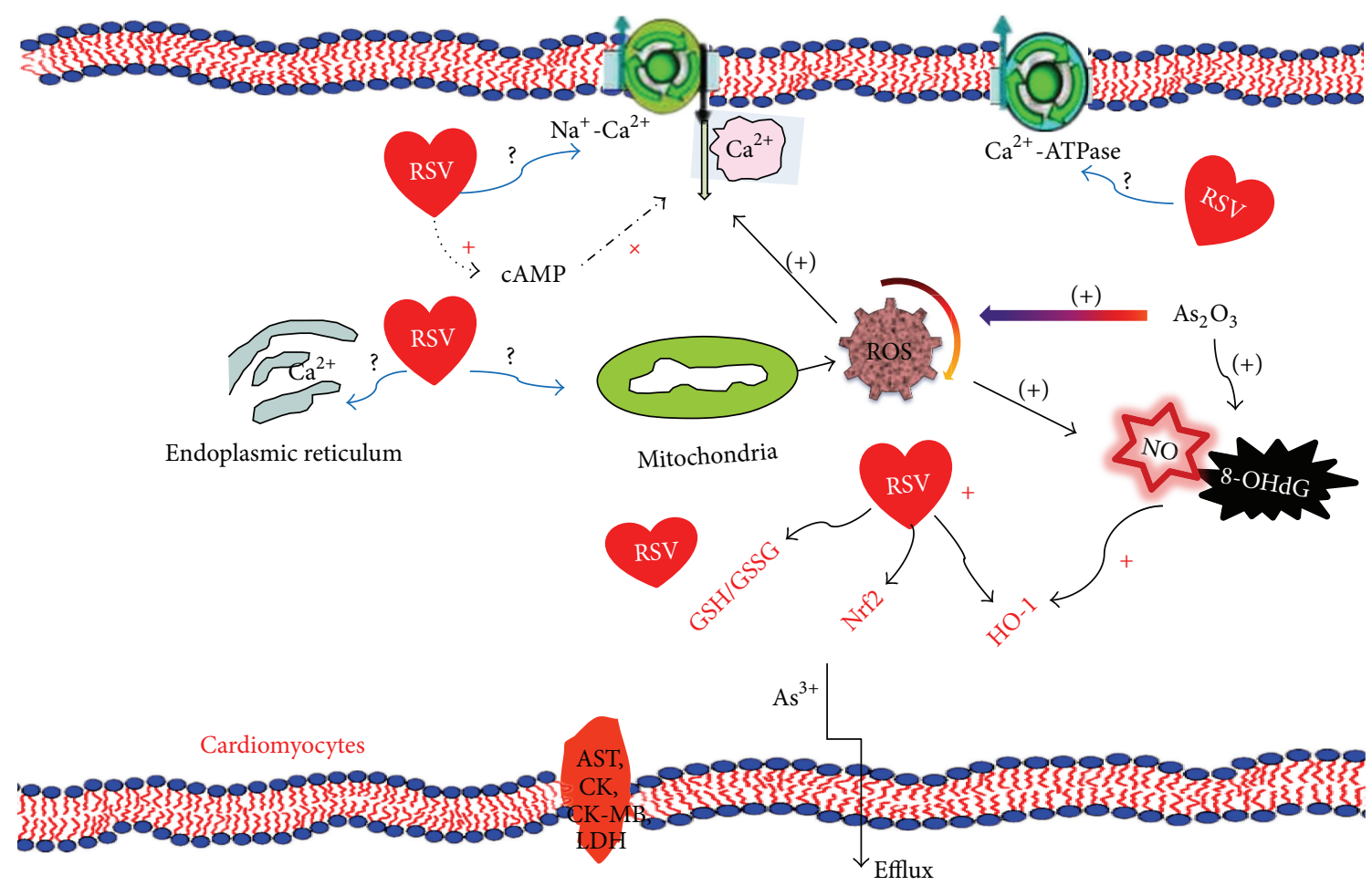

FIGURE 6: Summary indicating involvement of oxidative stress responses and the possible mechanism associated with $\mathrm{Nrf}_{2}-\mathrm{HO}_{-1}$ in $\mathrm{As}_{2} \mathrm{O}_{3}$ induced injury. $\mathrm{As}_{2} \mathrm{O}_{3}$ induces the increase of ROS production from mitochondria in rat cardiac myocytes. ROS triggers Ca ${ }^{2+}$ accumulation, 8-OHdG formation, and GSH deficiency in cardiocytes. RSV scavenges ROS, reduces DNA damage (indicated with 8-OHdG), and preserves GSH and $\mathrm{Ca}^{2+}$ homeostasis. Additionally, Nrf2-HO-1, a key signaling pathway involved in cellular oxidative responses, is prohibited by RSV $\mathrm{As}_{2} \mathrm{O}_{3}$-induced downregulation. Taken together, RSV protects the integrity of cardiac myocytes after exposure to $\mathrm{As}_{2} \mathrm{O}_{3}$, thereby decreasing AST, CK, CK-MB, and LDH release, as well as facilitating arsenic efflux. Future studies are required to clarify the mechanism for protecting RSV against $\mathrm{As}_{2} \mathrm{O}_{3}$-induced cardiotoxicity in endoplasmic reticulum and mitochondria. ROS: reactive oxygen species; RSV: resveratrol; + or (+) stands for positive improvement or negative improvement.

Unfortunately, several approaches which were able to reduce tissue damage in animal or cell culture models are either not applicable to humans or failed to be beneficial in clinical trials $[27,28]$.

Resveratrol, is an antioxidant found in grapes, red wine, and some other botanical sources with a wide range of biological and pharmacological properties, for example, antiinflammatory, cardioprotection activity, and anticancer properties [29, 30]. Haskó and Pacher [31] had demonstrated that resveratrol regulated endothelial $\mathrm{Nrf} 2$ activation. Therefore, resveratrol administration before $\mathrm{As}_{2} \mathrm{O}_{3}$ treatment diminished $\mathrm{As}_{2} \mathrm{O}_{3}$-induced ROS and 8-OHdG generation mediated by the partly maintenance of GSH/GSSH ratio and mRNA expression of Nrf2 and HO-1 (Figure 5).

Resveratrol has been shown to regulate cAMP through the competitive inhibition of cAMP-degrading phosphodiesterases, though it has not been clearly demonstrated in myocardial systems [13]. The intracellular cAMP-dependent modulate L-type $\mathrm{Ca}^{2+}$ channel has been widely recognized. In cardiac tissue, elevation of $\mathrm{Ca}^{2+}$ has been linked to various functional abnormalities, such as ventricular arrhythmia and contractile dysfunction. Also the increase of $\mathrm{Ca}^{2+}$ has been suggested to be one of the key signals leading to apoptosis $[11,32]$. In our studies, pretreatment with resveratrol attenuated $\mathrm{As}_{2} \mathrm{O}_{3}$-induced calcium overload and cAMP deficiency, suggesting that this might be attributed to the maintenance $\mathrm{Ca}^{2+}$ homeostasis by multiple possible ways (Figure 4). Notably, resveratrol administrated had no effect on $\mathrm{As}_{2} \mathrm{O}_{3}$-induced $\mathrm{NO}$ overload because of $\mathrm{NO}$ dual role in cardiac cells. Taken together, pretreatment with resveratrol ameliorated $\mathrm{As}_{2} \mathrm{O}_{3}$-induced myocardial damage in the heart (Figure 2). We cannot rule out that this result could be due to the improvements in cardiocyte function by heightening their aerobic capacity and autophagy to maintain tissue metabolic homeostasis in the presence of resveratrol $[33,34]$.

Sumi et al. [35] reported that cardiacmyocytes have a weak ability to excrete arsenic into the extracellular space. This sensitivity was attributed to the modest activation of Nrf2, leading to a decrease in the metabolism and excretion of arsenic. It is plausible that resveratrol can facilitate arsenic efflux to reduce the burden of arsenic in the heart mediated by the suppression from $\mathrm{As}_{2} \mathrm{O}_{3}$-induced $\mathrm{Nrf} 2$ downregulation (Figure 6).

In conclusion, the protective role of resveratrol against $\mathrm{As}_{2} \mathrm{O}_{3}$-induced cardiotoxicity is found by the maintenance of redox homeostasis viaNrf2-HO-1 pathway and facilitation of arsenic efflux. Resveratrol has been shown to have 
antiproliferative effects in various leukemic cell lines [36, 37]. To the best of our knowledge, our findings suggest that coadministration with resveratrol and $\mathrm{As}_{2} \mathrm{O}_{3}$ may be a novel therapeutic strategy for APL. Further investigation is warranted to elucidate another potential signal mechanism by which resveratrol protects $\mathrm{As}_{2} \mathrm{O}_{3}$-induced cardiac injury and another animal model.

\section{Acknowledgments}

This study was supported by the National Science Foundation Committee of China (31101868), Heilongjiang Province Foundation for Young Scholars (QC2010057), Heilongjiang Province Foundation for Postdoctor (LBH-Z10256), China Postdoctoral Science Foundation (20100481040), Special Foundation of China Postdoctoral Science Foundation (2012T50302), and Northeast Agricultural University Doctoral Foundation (2010RCB41) and Program for New Century Excellent Talents in Heilongjiang Provincial University (1253NCET-007).

\section{References}

[1] Y.S. Chang, K.H. Lu, H.J. Lee et al., "Synergistic apoptosisinducing antileukemic effects of arsenic trioxide and mucuna macrocarpa stem extract in human leukemic cells via a reactive oxygen species-dependent mechanism," Evidence-Based Complementary and Alternative Medicine, vol. 2012, Article ID 921430, 14 pages, 2012.

[2] K. Ohnishi, H. Yoshida, K. Shigeno et al., "Prolongation of the QT interval and ventricular tachycardia in patients treated with arsenic trioxide for acute promyelocytic leukemia," Annals of Internal Medicine, vol. 133, no. 11, pp. 881-885, 2000.

[3] B. S. L. Soignet, S. R. Frankel, D. Douer, M. S. Tallman, H. Kantarjian, and E. Calleja, "United States multicenter study of arsenic trioxide in relapsed acute promyelocytic leukemia," Journal of Clinical Oncology, vol. 19, no. 18, pp. 3852-3860, 2001.

[4] P. Westervelt, R. A. Brown, D. R. Adkins et al., "Sudden death among patients with acute promyelocytic leukemia treated with arsenic trioxide," Blood, vol. 98, no. 2, pp. 266-271, 2001.

[5] E. Ficker, Y. A. Kuryshev, A. T. Dennis et al., "Mechanisms of arsenic-induced prolongation of cardiac repolarization," Molecular Pharmacology, vol. 66, no. 1, pp. 33-44, 2004.

[6] S. Hirano, X. Cui, S. Li et al., "Difference in uptake and toxicity of trivalent and pentavalent inorganic arsenic in rat heart microvessel endothelial cells," Archives of Toxicology, vol. 77, no. 6, pp. 305-312, 2003.

[7] J.T. Hwang, D. Y. Kwon, O. J. Park, and M. S. Kim, "Resveratrol protects ROS-induced cell death by activating AMPK in H9c2 cardiac muscle cells," Genes and Nutrition, vol. 2, no. 4, pp. 323326, 2008.

[8] P. Manna, M. Sinha, and P. C. Sil, "Arsenic-induced oxidative myocardial injury: protective role of arjunolic acid," Archives of Toxicology, vol. 82, no. 3, pp. 137-149, 2008.

[9] J. Dudka, R. Gieroba, A. Korga et al., "Different effects of resveratrol on dose-related Doxorubicin-induced heart and liver toxicity," Evidence-Based Complementary and Alternative Medicine, vol. 2012, Article ID 606183, 10 pages, 2012.

[10] S. Das and D. K. Das, "Resveratrol: a therapeutic promise for cardiovascular diseases," Recent Patents on Cardiovascular Drug Discovery, vol. 2, no. 2, pp. 133-138, 2007.
[11] M. Sulaiman, M. J. Matta, N. R. Sunderesan, M. P. Gupta, M. Periasamy, and M. Gupta, "Resveratrol, an activator of SIRT1, upregulates sarcoplasmic calcium ATPase and improves cardiac function in diabetic cardiomyopathy," American Journal of Physiology: Heart and Circulatory Physiology, vol. 298, no. 3, pp. H833-H843, 2010.

[12] J. A. Baur, K. J. Pearson, N. L. Price et al., "Resveratrol improves health and survival of mice on a high-calorie diet," Nature, vol. 444, no. 7117, pp. 337-342, 2006.

[13] S.J. Park, F. Ahmad, A. Philp et al., "Resveratrol ameliorates aging-related metabolic phenotypes by inhibiting cAMP phosphodiesterases," Cell, vol. 148, no. 3, pp. 421-433, 2012.

[14] R. I. Tennen, E. Michishita Kioi, and K. F. Chua, "Finding a target for resveratrol," Cell, vol. 148, no. 3, pp. 387-389, 2012.

[15] X.Y. Zhao, G.Y. Li, Y. Liu et al., "Resveratrol protects against arsenic trioxide-induced cardiotoxicity in vitro and in vivo," British Journal of Pharmacology, vol. 154, no. 1, pp. 105-113, 2008.

[16] D. P. Maxwell, Y. Wang, and L. McIntosh, "The alternative oxidase lowers mitochondrial reactive oxygen production in plant cells," Proceedings of the National Academy of Sciences of the United States of America, vol. 96, no. 14, pp. 8271-8276, 1999.

[17] J. Lakritz, C. G. Plopper, and A. R. Buckpitt, "Validated highperformance liquid chromatography-electrochemical method for determination of glutathione and glutathione disulfide in small tissue samples," Analytical Biochemistry, vol. 247, no. 1, pp. 63-68, 1997.

[18] I. Csanaky and Z. Gregus, "Effect of selenite on the disposition of arsenate and arsenite in rats," Toxicology, vol. 186, no. 1-2, pp. 33-50, 2003.

[19] S. Kimura, "New generation of $\mathrm{Ca}^{2+}$ indicators with greatly improved fluorescence properties," Tanpakushitsu Kakusan Koso, vol. 52, no. 13, pp. 1758-1759, 2007.

[20] X. Shi and B. Zhou, "The role of Nrf2 and MAPK pathways in PFOS-induced oxidative stress in zebrafish embryos," Toxicological Sciences, vol. 115, no. 2, pp. 391-400, 2010.

[21] H. V. Aposhian and M. M. Aposhian, "Arsenic toxicology: five questions," Chemical Research in Toxicology, vol. 19, no. 1, pp. $1-15,2006$.

[22] G. Y. Oudit, M. G. Trivieri, N. Khaper et al., "Taurine supplementation reduces oxidative stress and improves cardiovascular function in an iron-overload murine model," Circulation, vol. 109, no. 15, pp. 1877-1885, 2004.

[23] Y. Yang, S. W. Chan, M. Hu, R. Walden, and B. Tomlinson, "Effects of some common food constituents on cardiovascular disease," ISRN Cardiology, vol. 2011, Article ID 397136, 16 pages, 2011.

[24] E. Bassenge, O. Sommer, M. Schwemmer, and R. Bünger, "Antioxidant pyruvate inhibits cardiac formation of reactive oxygen species through changes in redox state," American Journal of Physiology: Heart and Circulatory Physiology, vol. 279, no. 5, pp. H2431-H2438, 2000.

[25] D.X. Hou, Y. Korenori, S. Tanigawa et al., "Dynamics of Nrf2 and Keap1 in ARE-mediated NQO1 expression by wasabi 6(methylsulfinyl)hexyl isothiocyanate," Journal of Agricultural and Food Chemistry, vol. 59, no. 22, pp. 11975-11982, 2011.

[26] J. A. Baur and D. A. Sinclair, "Therapeutic potential of resveratrol: the in vivo evidence," Nature Reviews Drug Discovery, vol. 5, no. 6, pp. 493-506, 2006.

[27] I. El Hamamsy, L.M. Stevens, M. Carrier et al., "Effect of intravenous $\mathrm{N}$-acetylcysteine on outcomes after coronary 
artery bypass surgery: a randomized, double-blind, placebocontrolled clinical trial," Journal of Thoracic and Cardiovascular Surgery, vol. 133, no. 1, pp. 7-12, 2007.

[28] S. Kinlay, D. Behrendt, J. C. Fang et al., "Long-term effect of combined vitamins $\mathrm{E}$ and $\mathrm{C}$ on coronary and peripheral endothelial function," Journal of the American College of Cardiology, vol. 43, no. 4, pp. 629-634, 2004.

[29] M. Joseph, H. Tze chen, and Z. R. Wang, "Cardioprotection by resveratrol: a review of effects/targets in cultured cells and animal tissues," American Journal of Cardiovascular Disease, vol. 1, pp. 38-47, 2011.

[30] W. Zhang, J. Xue, M. Ge, M. Yu, L. Liu, and Z. Zhang, "Resveratrol attenuates hepatotoxicity of rats exposed to arsenic trioxide," Food and Chemical Toxicology, vol. 51, pp. 87-92, 2013.

[31] G. Haskó and P. Pacher, "Endothelial Nrf2 activation: a new target for resveratrol?" American Journal of Physiology: Heart and Circulatory Physiology, vol. 299, no. 1, pp. H10-H12, 2010.

[32] R. M. Shaw and Y. Rudy, "Ionic mechanisms of propagation in cardiac tissue: roles of the sodium and L-type calcium currents during reduced excitability and decreased gap junction coupling," Circulation Research, vol. 81, no. 5, pp. 727-741, 1997.

[33] M. Lagouge, C. Argmann, Z. Gerhart-Hines et al., "Resveratrol improves mitochondrial function and protects against metabolic disease by activating SIRT1 and PGC-1 $\alpha$," Cell, vol. 127, no. 6, pp. 1109-1122, 2006.

[34] S. Orrenius, V. O. Kaminskyy, and B. Zhivotovsky, "Autophagy in toxicology: cause or consequence?" The Annual Review of Pharmacology and Toxicology, vol. 53, pp. 275-97, 2013.

[35] D. Sumi, T. Sasaki, H. Miyataka, and S. Himeno, "Rat H9c2 cardiac myocytes are sensitive to arsenite due to a modest activation of transcription factor Nrf2," Archives of Toxicology, vol. 85, no. 12, pp. 1509-1516, 2011.

[36] M. Athar, J. H. Back, X. Tang et al., "Resveratrol: a review of preclinical studies for human cancer prevention," Toxicology and Applied Pharmacology, vol. 224, no. 3, pp. 274-283, 2007.

[37] J. M. Matés, J. A. Segura, F. J. Alonso, and J. Márquez, "Intracellular redox status and oxidative stress: implications for cell proliferation, apoptosis, and carcinogenesis," Archives of Toxicology, vol. 82, no. 5, pp. 273-299, 2008. 


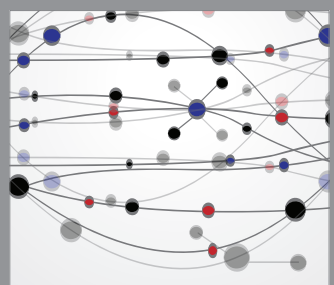

The Scientific World Journal
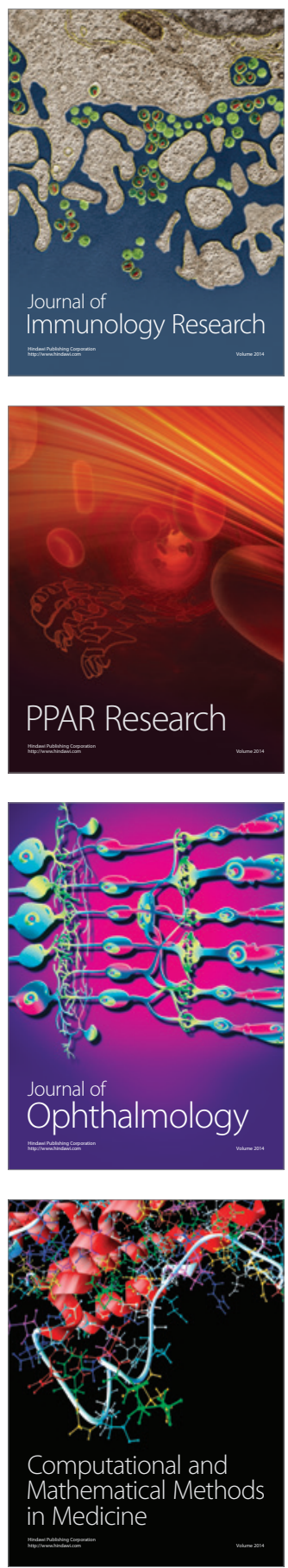

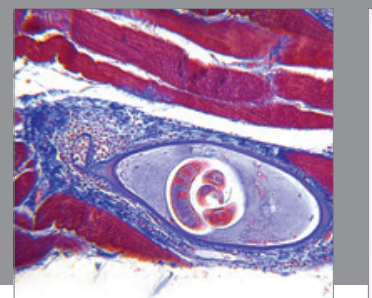

Gastroenterology

Research and Practice
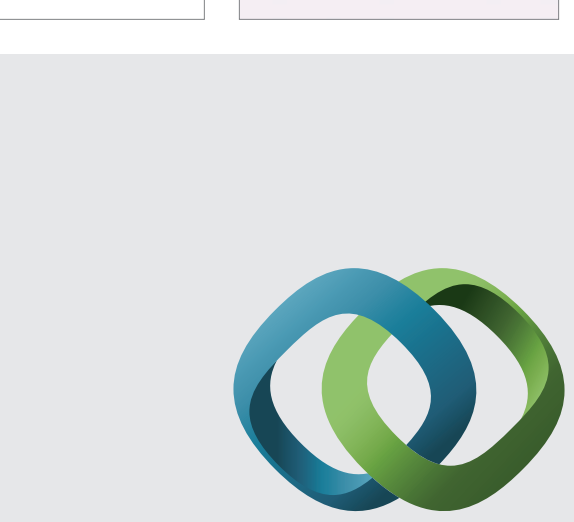

\section{Hindawi}

Submit your manuscripts at

http://www.hindawi.com
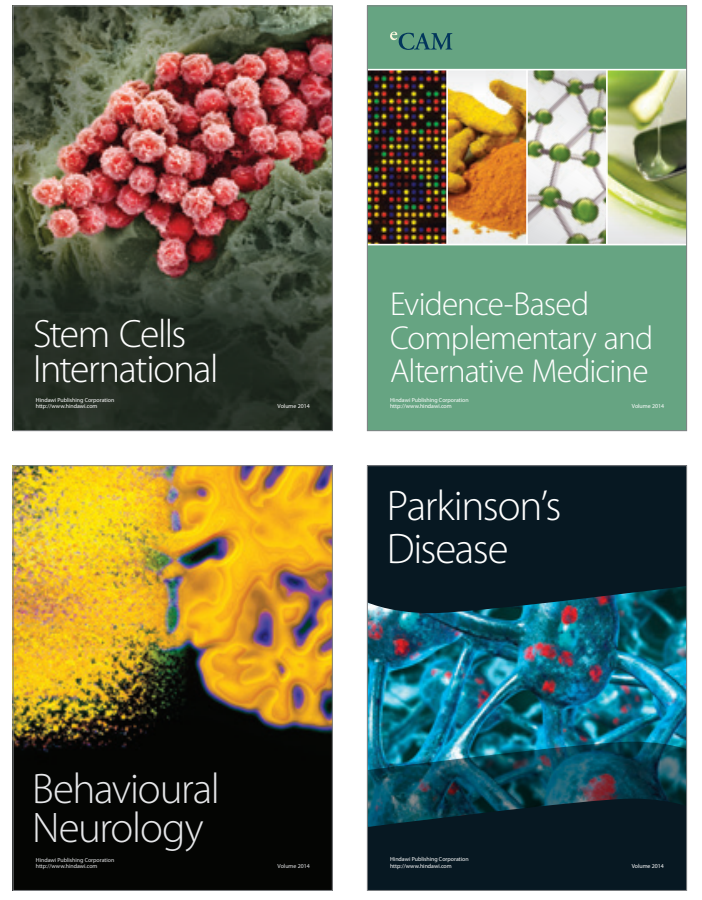
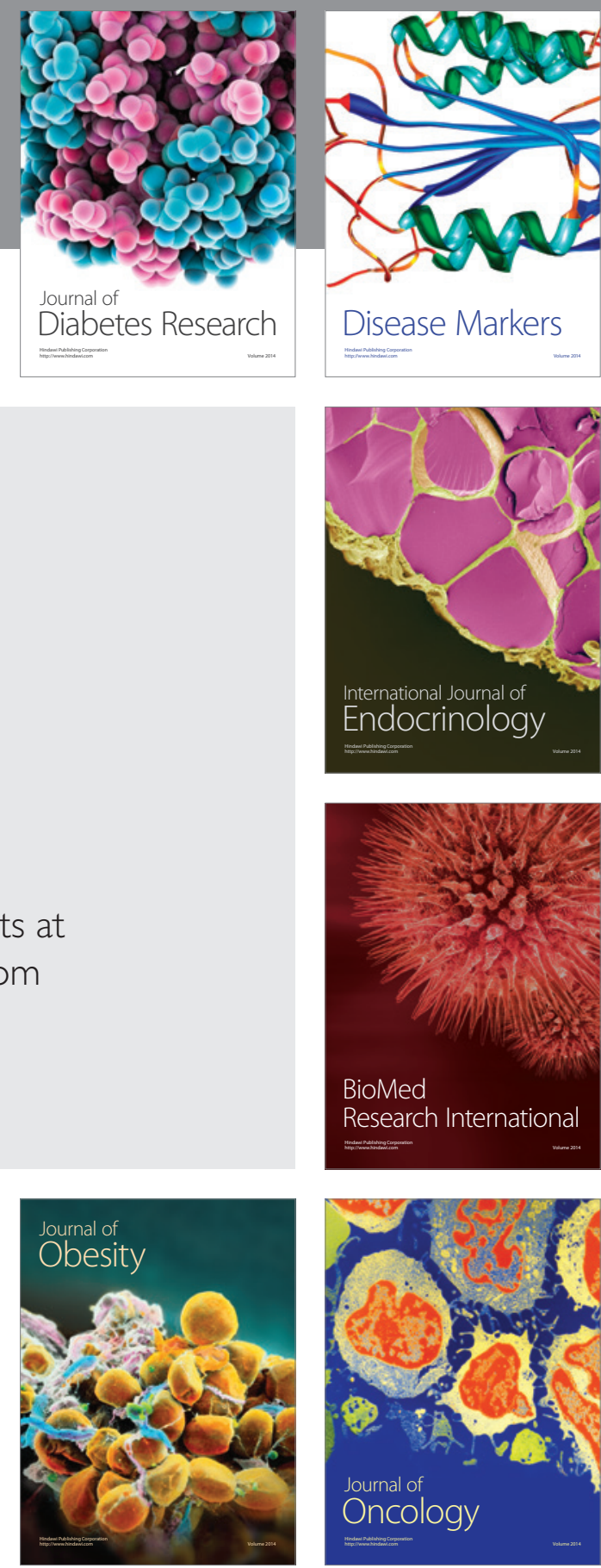

Disease Markers
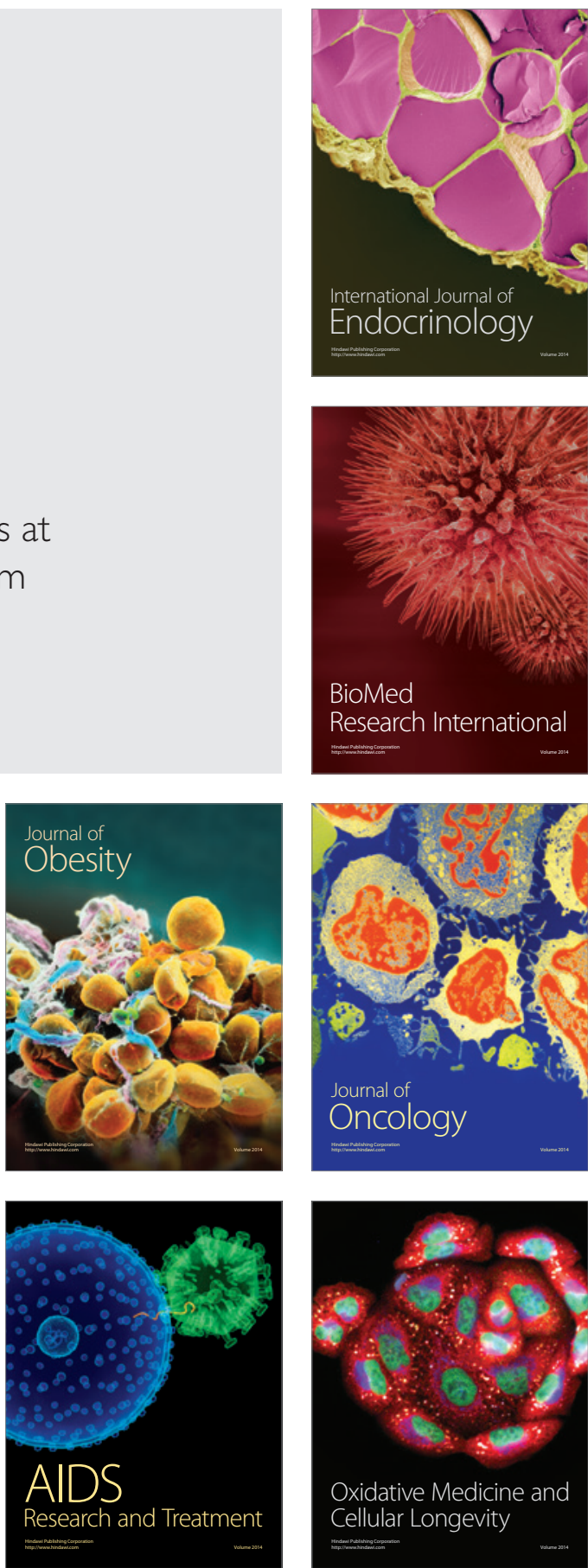